\title{
Broken bucks: money funds that took taxpayer guarantees in 2008
}

\author{
Linus Wilson ${ }^{1}$ (1)
}

Revised: 4 June 2020 / Published online: 3 August 2020

(c) Springer Nature Limited 2020

\begin{abstract}
This is the first study to look at the characteristics of funds accepting the $\$ 2.7$ trillion taxpayer guarantee of money market mutual funds during the 2008 financial crisis. Fund shares that benefited from Federal Reserve's asset-backed commercial paper program were significantly more likely to get bailed out by taxpayers and sponsors. The paper tests if funds adhering to the SEC's 2010 liquidity reforms prior to their enactment were less likely to be bailed out in 2008. Finally, it examines if funds subject to the 2014 floating NAV regulations were more likely to be bailed out in 2008 .
\end{abstract}

Keywords Breaking the buck $\cdot$ Bailout $\cdot$ Dodd-Frank $\cdot$ DLA $\cdot$ Exchange rate stabilization fund $\cdot$ Floating NAV $\cdot$ Financial Stability Oversight Council (FSOC) $\cdot$ Guarantees $\cdot$ Liquidity $\cdot$ Money market mutual funds $\cdot$ Regulation $\cdot$ SEC $\cdot$ Reserve Primary Fund $\cdot$ Securities and Exchange Commission $\cdot$ U.S. Treasury $\cdot$ WAL $\cdot$ WAM $\cdot$ WLA

JEL Classification $\mathrm{G} 01 \cdot \mathrm{G} 18 \cdot \mathrm{G} 22 \cdot \mathrm{G} 23 \cdot \mathrm{G} 28 \cdot \mathrm{H} 12 \cdot \mathrm{H} 81 \cdot \mathrm{L} 5$

\section{Introduction}

This is the first study to analyze the characteristics of funds accepting the U.S Treasury's Temporary Guarantee of Money Market Mutual Funds (TTGMMMF). Indeed, this paper is the only source that provides a complete list of fund families participating in this unprecedented guarantee of money market mutual funds. Here, it is estimated that this guarantee of money market mutual funds from September 19,2008 , to September 18, 2009, guaranteed $\$ 2.7$ trillion in money market mutual fund assets from its onset.

Kim (2019) looks at redemption behavior of investors before and after funds reported accepting taxpayer guarantees. That paper does not look at the characteristics of funds receiving and not receiving U.S. Treasury backing as the present paper does. Moreover, because it identifies participants by announcements, its sample is much smaller than this study which obtained a complete list of funds by way of a Freedom of Information Act (FOIA) request. The present study has identified 146 fund sponsors receiving U.S. Treasury guarantees to Kim (2019)'s 75 fund sponsors accepting TTGMMF guarantees. Moreover, unlike Kim (2019),

Linus Wilson

linus.wilson@louisiana.edu

1 University of Louisiana at Lafayette, Lafayette, USA which does not mention the SEC's regulatory responses to the money fund bailouts, that is the focus of this study.

The financial industry has been the target of greater regulation since the financial crisis of 2007-to-2009 and the money market mutual fund industry is no exception. Money market mutual funds are unique among investment companies because under rule $2 \mathrm{a}-7$ because they are allowed to maintain a stable net asset value (NAV) of $\$ 1.00$ per share. That means that investors can redeem fund shares for $\$ 1.00$ even if the NAV falls to $\$ 0.995$ as explained by Fisch and Roiter (2012) and Birdthistle (2010). SEC (2014) required institutional prime and municipal funds to report NAV to the basis point (four decimal places) in an effort to make runs less likely. This is the only paper to test if institutional, prime, and municipal funds were more likely to be bailed out in the last financial crisis.

There is a healthy debate about the floating NAV reforms for money funds. Fisch (2015) argues that explicit sponsor support would be more effective than a floating NAV to prevent runs. In contrast, Baily et al. (2011) argues that floating NAV is one way to forestall rapid withdrawals in panics. In contrast, Gandia and Gordon (2014) found European money market funds with floating NAV experienced similar outflows during the "Lehman week" crisis as fixed NAV funds in the USA. Witmer (2016), on the other hand, finds that money funds in countries with floating NAV experienced 
significantly fewer outflows during the Reserve Primary Fund event horizon than money funds in countries with fixed NAVs. Parlatore (2016) develops a theoretical model in which total supply of liquidity increases with floating NAV funds. Alternatively, La Spada (2018) argues that floating NAV requirements could lead to funds taking on more risk when risk-free rates are low due to tournament incentives. This paper will not settle the ongoing debate whether or not fixed or floating NAVs will prevent future money fund crises.

In 2010, the Securities and Exchange Commission (SEC) passed a series of new regulations to improve the liquidity of money market mutual funds so that they would be less vulnerable to large numbers of redemptions in their fund shares. This paper empirically tests if these reforms would have prevented the bailouts in the 2007-to-2009 financial crisis. It is shown that funds, which had weighted average maturities (WAM) less than 60 days, were significantly less likely to receive bailouts from taxpayers or their mutual fund family sponsors. That was one of five new liquidity requirements from the 2010 reforms which were tested. In addition, funds less exposed to securities that increase a fund's weighted average life (WAL), auction rate securities, were found to be less likely to receive taxpayer bailouts. The study finds little evidence that other new regulations about the daily liquidity, weekly liquidity, and second-tier commercial paper holdings were associated with a decreased propensity for taxpayer and fund sponsor bailouts.

On September 16, 2008, after Lehman Brother's chapter 11 filing triggered the largest commercial paper default in U.S. history, the Reserve Primary Fund "broke the buck" because of its Lehman Brother's holdings, posting a NAV below $\$ 0.995 .{ }^{1}$ Schmidt et al. (2016) details how prime, institutional money market funds were exposed to runs in this period. Morgenson (2012) writes that U.S. Treasury responded in September 19, 2008, by announcing that it would use the $\$ 50$ billion exchange rate stabilization fund to guarantee that insured money market funds would not break the buck for fees ranging from 1 to 1.5 basis points per quarter.

The rarity of money funds breaking the buck masks their greater risk. Prior 2007-to-2009 financial crisis, Moody's (2010) argues there were no less than 146 instances where voluntary fund sponsor bailouts prevented funds

\footnotetext{
1 This was not the only instance of a money fund breaking the buck between 1980 and 2009. Moody's (2010) explains that Reserve Management, the sponsor of the Reserve Primary Fund, had another sister fund based in the British Virgin Islands that broke the buck. Ultimate recoveries for the Reserve Primary Fund and its sister fund were $\$ 0.99$ and \$0.86 per share. In 1994, a fund invested in inverse floaters, securities with complex bets on interest rates, broke the buck, returning $\$ 0.96$ to shareholders.
}

from breaking the buck since 1980. In the financial crisis, Moody's (2010) identified 62 instances of sponsor support that prevented funds from breaking the buck. Based on the Moody's (2010) estimates, Appendix in Sect. 8 explains that the fair cost of insuring $\$ 2.716$ trillion of money market assets should have been 13 -to-33 basis points per year not the 4-to- 6 basis points charged.

This paper is similar to McCabe (2010) and Kacperczyk and Schnabl (2013) in that it looks at the factors associated with discretionary sponsor bailouts in the financial crisis of 2007 and 2008. Yet, unlike McCabe (2010) and Kacperczyk and Schnabl (2013) this paper looks at how the 2010 reforms proposals could have mitigated the need for sponsor bailouts.

Similar to Duygan-Bump et al. (2013), this paper looks at which funds accepted Federal Reserve support during the financial crisis. Unlike that study, the present paper discovers that participation in the Federal Reserve's asset-backed commercial paper buying program is positively associated with a money fund's receiving taxpayer and sponsor bailouts.

SEC (2012) is the only study of which the author is aware that rigorously tests the effectiveness of the 2010 money market reforms. That study uses Monte Carlo simulations to conclude that the reduction in the maximum weighted average maturity in fund assets (WAM) from 90 to 60 days increased money funds' resilience to shocks. The empirical results here complement SEC (2012) because this paper finds that funds with WAM below 60 days were significantly less likely to receive sponsor support or taxpayer guarantees.

This paper proceeds as follows. In Sect. 2, the sources of data are discussed. In Sect. 3, the five quantifiable reforms from the SEC's 2010 money fund regulation are discussed. In Sect. 4, hypotheses are developed. In Sect. 5, the factors associated with money funds receiving a taxpayer bailout are discussed. In particular, funds receiving taxpayer guarantees had higher weighted average maturities (WAM) and greater exposure to auction rate securities with long weighted average lives (WAL). Prime funds, higher yielding funds, older funds, large funds, and funds which saw positive inflows during the week that Lehman failed were more likely to get a taxpayer guarantees. In Sect. 6, the factors associated with sponsor support are tested. It is found that having WAM below 60 days reduced the likelihood of sponsor bailouts. Moreover, the funds with the lowest NAV's that obtained taxpayer insurance were significantly more likely to get sponsor bailouts. In Sect. 7, the paper concludes. In Appendix Sect. 8, the Moody's (2010) data are used to estimate the fair cost of insuring money funds from breaking the buck. 


\section{Data}

The sample includes money market mutual fund shares tracked by CRSP's mutual fund database. This is all funds with Lipper classifications of institutional money market funds, institutional U.S. government money market funds, institutional U.S. Treasury money market funds, money market instrument funds, U.S. government money market funds, and U.S. Treasury money market funds. This database tracks the assets, expense ratios, fund age in years, and yields used in this study. ${ }^{2}$ There were 1565 different mutual fund share classes that fit these criteria on September 30, 2008, the closest month end date to the time when the money market mutual fund guarantee began.

The author obtained data on the participating funds in the U.S. Treasury's Temporary Guarantee of Money Market Mutual Funds (TTGMMMF), to which we will refer as the taxpayer guarantee or U.S. Treasury guarantee, from a Freedom of Information Act (FOIA) request. The U.S. Treasury listed 358 funds or groups of funds that took advantage of this guarantee. That represented 1424 different share classes which the author matched by hand to the CRSP database of mutual fund share classes. The FOIA list is a unique data set that has never been studied prior to the drafting of this paper. The U.S. Treasury has never publically released the names of participating funds and the individual fees paid by these funds. Table 7 is the first complete listing of participating mutual fund companies. Officials from the U.S. Treasury told the corresponding author that the U.S. Treasury had lost all records of what turned out to be a $\$ 2.7$ trillion taxpayer guarantee. The U.S. Treasury pieced together records of this massive insurance program in part from the e-mail accounts of officials who had long since departed from the U.S. Treasury. This request gave a complete listing of participating mutual funds or mutual fund groups. Funds signed up for this insurance program between September 29, 2008, and October 8, 2008.

From the FOIA request, the author obtained the insurance fees charged at the beginning of the program for 284 of the 358 funds listed in the FOIA request. Yet, the U.S. Treasury chose to hide the amounts guaranteed and insurance payments at the request of the sponsors of 74 of the money market mutual funds listed. The author has appealed the decision to hide this data from the general public. Nevertheless, we are able to obtain the insurance rates and insurance fees paid from annual and semi-annual reports filed with the SEC for 65 of 74 funds that wanted to hide their involvement in the taxpayer guarantee. Thus, in total we have the insurance

\footnotetext{
${ }^{2}$ Fund age in years was defined as the years from the fund's inception to the start of the U.S. Treasury's guarantee on September 19, 2008. A 365 day year was assumed to convert days into years.
}

fee rates paid for 349 out of 358 funds and 1414 of 1424 share classes which were both guaranteed by taxpayers and tracked by CRSP. We know that funds that paid a 1 basis point insurance rate had floating Net Asset Values (NAVs) at or above $\$ 0.9975$ per share on September 19, 2008. Participating funds that paid a rate of 1.5 basis points had NAVs at or above $\$ 0.995$ but below $\$ 0.9975$. Thus, we created a dummy variable equal to 1 if the funds identified by the U.S. Treasury paid rates between 1.05 and 1.5 basis points. Several names on the FOIA list consisted of several funds which paid a blended rate to the U.S. Treasury.

Since the amount guaranteed is a linear function of the rate and the guarantee fees, we could accurately estimate the assets guaranteed with a little rounding. The only exceptions were five different AIM-Invesco funds, the Anchor Series Trust, Kinetics Government Money Market Fund, the Strategic Partners Mutual Funds, and the WB Capital Mutual Funds. Those funds' poor disclosures, which were outside the industry norm, prevented the author and, more importantly, the funds' investors from knowing the insurance fees and rates paid for the taxpayer guarantee.

In Table 1, we list the fund sponsors who received taxpayer guarantees and the amount of taxpayer guarantees. In total, the U.S. Treasury guaranteed in excess of \$2.7 trillion in money market assets in 2008. This estimate is based on the Treasury's response to the FOIA for 284 of the 358 funds, SEC filings for another 65 funds, and estimates based on the mutual fund assets of the remaining 9 from the CRSP mutual fund database as of September 30, 2008. The author aggregated that data by fund sponsor to produce Table 1 . This is the only complete listing of fund sponsors participating in the \$2.7 trillion taxpayer guarantee.

We use other measures of money market funds' distress during the financial crisis of 2007 and 2008. Agapova (2011) finds that mutual fund sponsors often park cash of nonmoney funds in money market mutual funds. Thus, sponsors not only have reputational reasons for bailing out money funds, they also may benefit other sponsor funds with assets in the assisted money fund. Hensler (2012) is a list prepared by the SEC of 313 instances where sponsors applied for waivers of related party transaction rules so that the sponsor could bail out a money fund. Formally, Hensler (2012, p. 1) defines sponsor support as,

... purchasing securities out of a fund at amortized cost value, entering into a capital support agreement for a fund, purchasing a letter of credit to support a fund, contributing a cash gift to a fund, providing a guarantee or put for a fund portfolio security, and obtaining no-action relief to buy out any security at amortized cost value.

The Investment Company Institute (ICI), a trade group representing the mutual fund industry, opposes the SEC's 
Table 1 Money market mutual fund sponsors ranked by the assets guaranteed by taxpayers beginning on September 19, 2008

\begin{tabular}{|c|c|c|c|c|c|}
\hline & Fund sponsor & $\begin{array}{l}\text { Amount insurec } \\
\text { in billions }\end{array}$ & & Fund sponsor & $\begin{array}{l}\text { Amount } \\
\text { insured in } \\
\text { billions }\end{array}$ \\
\hline \multicolumn{6}{|c|}{ Panel A } \\
\hline 1 & FIDELITY & $\$ 432.96$ & 51 & HARTFORD MUTUAL FUNDS & $\$ 4.90$ \\
\hline 2 & JPMORGAN & $\$ 242.68$ & 52 & INVESCO/AIM & $\$ 4.57$ \\
\hline 3 & FEDERATED INVESTORS & $\$ 219.56$ & 53 & PFM ASSET MANG. & $\$ 4.19$ \\
\hline 4 & CHARLES SCHWAB & $\$ 195.00$ & 54 & PUTNAM INVESTMENT MANG. & $\$ 4.01$ \\
\hline 5 & VANGUARD GROUP & $\$ 192.47$ & 55 & PNC CAPITAL ADVISORS & $\$ 3.36$ \\
\hline 6 & BLACKROCK & $\$ 147.40$ & 56 & BB\&T ASSET MANG. & $\$ 2.94$ \\
\hline 7 & WELLS FARGO & $\$ 112.72$ & 57 & BROWN BROTHERS HARRIMAN & $\$ 2.82$ \\
\hline 8 & LEGG MASON & $\$ 102.32$ & 58 & MUNDER CAPITAL MANG. & $\$ 2.73$ \\
\hline 9 & GOLDMAN SACHS \& CO. & $\$ 100.17$ & 59 & ASTON ASSET MANG. & $\$ 2.68$ \\
\hline 10 & MORGAN STANLEY & $\$ 86.24$ & 60 & FIRST AMERICAN FUND ADVISORS & $\$ 2.60$ \\
\hline 11 & NORTHERN TRUST INV. & $\$ 82.26$ & 61 & EQUITRUST INVESTMENT MGMT. & $\$ 2.48$ \\
\hline 12 & COLUMBIA FUNDS & $\$ 68.37$ & 62 & MFS INVESTMENT MANG. & $\$ 2.44$ \\
\hline 13 & DREYFUS & $\$ 67.66$ & 63 & BANK OF HAWAII & $\$ 2.41$ \\
\hline 14 & UBS & $\$ 60.65$ & 64 & THRIVENT FIN. FOR LUTHERANS & $\$ 2.32$ \\
\hline 15 & EVERGREEN INVESTMENT MANG. & $\$ 53.90$ & 65 & HUNTINGTON ASSET ADVISORS & $\$ 2.28$ \\
\hline 16 & DWS INVESTMENTS & $\$ 52.56$ & 66 & AIG/SUNAMERICA & $\$ 2.20$ \\
\hline 17 & HSBC & $\$ 31.19$ & 67 & PIONEER INVESTMENT MANG. & $\$ 2.05$ \\
\hline 18 & STATE STREET & $\$ 27.93$ & 68 & AMERICAN PERFORMANCE FUNDS & $\$ 2.04$ \\
\hline 19 & TD ASSET MANAGEMENT & $\$ 27.39$ & 69 & METLIFE & $\$ 2.03$ \\
\hline 20 & AMERICAN FUNDS & $\$ 24.15$ & 70 & ALLIANCEBERNSTEIN & $\$ 1.94$ \\
\hline 21 & EDWARD D JONES \& CO. & $\$ 19.16$ & 71 & GLENMEDE INVESTMENT MANG. & $\$ 1.78$ \\
\hline 22 & VOYAGEUR ASSET MANG. & $\$ 17.19$ & 72 & RYDEX INVESTMENTS & $\$ 1.78$ \\
\hline 23 & T ROWE PRICE & $\$ 16.20$ & 73 & MAINSTAY FUNDS & $\$ 1.71$ \\
\hline 24 & SEI GROUP & $\$ 15.76$ & 74 & JJB HILLIARD WL LYONS & $\$ 1.67$ \\
\hline 25 & RIDGEWORTH FUNDS & $\$ 15.42$ & 75 & TCW INVESTMENT MANG. & $\$ 1.64$ \\
\hline 26 & OPPENHEIMERFUNDS & $\$ 14.98$ & 76 & WILLIAM BLAIR \& CO. & $\$ 1.63$ \\
\hline 27 & BARCLAYS GLOBAL INVESTORS & $\$ 14.42$ & 77 & GE ASSET MANG. & $\$ 1.59$ \\
\hline 28 & JANUS CAPITAL MANG. & $\$ 11.97$ & 78 & TIAA-CREF & $\$ 1.59$ \\
\hline 29 & AMERICAN BEACON ADVISORS & $\$ 11.97$ & 79 & CALVERT FUNDS & $\$ 1.50$ \\
\hline 30 & USAA INVESTMENT MANG. & $\$ 10.32$ & 80 & TOUCHSTONE ADVISORS & $\$ 1.35$ \\
\hline 31 & FRANKLIN TEMPLETON INV. & $\$ 10.10$ & 81 & WADDELL \& REED INV. MGMT CO. & $\$ 1.29$ \\
\hline 32 & FIFTH THIRD ASSET MANG. & $\$ 9.03$ & 82 & SCOUT INVESTMENT ADVISORS & $\$ 1.25$ \\
\hline 33 & REICH \& TANG ASSET MANG. & $\$ 9.03$ & 83 & LINCOLN NATIONAL & $\$ 1.23$ \\
\hline 34 & MTB INVESTMENT ADVISORS & $\$ 8.53$ & 84 & PAYDEN \& RYGEL & $\$ 1.17$ \\
\hline 35 & ALLEGIANT ASSET MANG. & $\$ 8.23$ & 85 & JOHN HANCOCK & $\$ 1.10$ \\
\hline 36 & AMERICAN CENTURY & $\$ 8.10$ & 86 & FORWARD MANG. & $\$ 1.10$ \\
\hline 37 & VICTORY CAPITAL MANG. & $\$ 7.22$ & 87 & TRANSAMERICA & $\$ 1.09$ \\
\hline 38 & RIVERSOURCE INVESTMENTS & $\$ 7.21$ & 88 & PROFUNDS GROUP & $\$ 1.09$ \\
\hline 39 & CREDIT SUISSE ASSET MANG. & $\$ 7.05$ & 89 & GUIDESTONE FUNDS TRUST & $\$ 1.09$ \\
\hline 40 & CITY NATIONAL ASSET MANG. & $\$ 6.96$ & 90 & CALLAHAN CREDIT UNION & $\$ 1.00$ \\
\hline 41 & M \& I INVESTMENT MANG. & $\$ 6.87$ & 91 & GABELLI FUNDS & $\$ 1.00$ \\
\hline 42 & WILMINGTON FUNDS & $\$ 6.55$ & 92 & MASSMUTUAL & $\$ 0.92$ \\
\hline 43 & ING & $\$ 6.48$ & 93 & PAYPAL ASSET MANG. & $\$ 0.82$ \\
\hline 44 & RUSSELL INVESTMENT GROUP & $\$ 6.43$ & 94 & ECLIPSE FUNDS & $\$ 0.82$ \\
\hline 45 & HIGHMARK CAPITAL MANG. & $\$ 6.40$ & 95 & VAN KAMPEN ASSET MANG. & $\$ 0.79$ \\
\hline 46 & MERRILL LYNCH & $\$ 6.18$ & 96 & PIMCO & $\$ 0.77$ \\
\hline 47 & HERITAGE ASSET MANG. & $\$ 6.18$ & 97 & TRUSTMARK INV. ADVISORS & $\$ 0.75$ \\
\hline
\end{tabular}


Table 1 (continued)

\begin{tabular}{|c|c|c|c|c|}
\hline & Fund sponsor & $\begin{array}{l}\text { Amount insured } \\
\text { in billions }\end{array}$ & Fund sponsor & $\begin{array}{l}\text { Amount } \\
\text { insured in } \\
\text { billions }\end{array}$ \\
\hline 48 & NATIONWIDE FUND ADVISORS & $\$ 5.38$ & EATON VANCE & $\$ 0.74$ \\
\hline 49 & PHOENIX INV. PARTNERS & $\$ 5.23$ & COMMERCE CAPITAL MARKETS & $\$ 0.74$ \\
\hline \multirow[t]{2}{*}{50} & JENNISON DRYDEN FUNDS & $\$ 5.19$ & WILLIAMS CAPITAL MANG. & $\$ 0.70$ \\
\hline & & Fund sponsor & & $\begin{array}{l}\text { Amount } \\
\text { insured in } \\
\text { billions }\end{array}$ \\
\hline \multicolumn{5}{|c|}{ Panel B } \\
\hline 100 & & \multicolumn{2}{|c|}{ ALPINE WOODS CAPITAL INV. } & $\$ 0.69$ \\
\hline 101 & & \multicolumn{2}{|l|}{ MONARCH INV. ADVISORS } & $\$ 0.629$ \\
\hline 102 & & \multicolumn{2}{|l|}{ DELAWARE MANG. CO. } & $\$ 0.548$ \\
\hline 103 & & \multicolumn{2}{|l|}{ NORTHWESTERN MUTUAL } & $\$ 0.545$ \\
\hline 104 & & \multicolumn{2}{|c|}{ US GLOBAL INVESTORS FUNDS } & $\$ 0.541$ \\
\hline 105 & & \multicolumn{2}{|l|}{ GW CAPITAL MANG. } & $\$ 0.523$ \\
\hline 106 & & \multicolumn{2}{|c|}{ AMBASSADOR CAPITAL MANG. } & $\$ 0.501$ \\
\hline 107 & & \multicolumn{2}{|l|}{ CALIFORNIA FUNDS } & $\$ 0.407$ \\
\hline 108 & & \multicolumn{2}{|l|}{ OHIO NATIONAL FUND } & $\$ 0.385$ \\
\hline 109 & & \multicolumn{2}{|l|}{ IVY INVESTMENT MANG. } & $\$ 0.328$ \\
\hline 110 & & \multicolumn{2}{|l|}{ HEWITT } & $\$ 0.325$ \\
\hline 111 & & \multicolumn{2}{|l|}{ BURNHAM ASSET MANG. } & $\$ 0.284$ \\
\hline 112 & & \multicolumn{2}{|l|}{ NATIXIS ASSET MANG. } & $\$ 0.278$ \\
\hline 113 & & \multicolumn{2}{|l|}{ ONEAMERICA } & $\$ 0.265$ \\
\hline 114 & & \multicolumn{2}{|l|}{ STATE FARM } & $\$ 0.253$ \\
\hline 115 & & \multicolumn{2}{|l|}{ EULAV ASSET MANG. } & $\$ 0.251$ \\
\hline 116 & & \multicolumn{2}{|c|}{ HARBOR CAPITAL ADVISORS } & $\$ 0.251$ \\
\hline 117 & & \multicolumn{2}{|l|}{ SELIGMAN FUNDS } & $\$ 0.238$ \\
\hline 118 & & \multicolumn{2}{|l|}{ FIRST INVESTORS MANG. } & $\$ 0.235$ \\
\hline 119 & & \multicolumn{2}{|c|}{ BISHOP STREET CAPITAL MANG. } & $\$ 0.216$ \\
\hline 120 & & \multicolumn{2}{|l|}{ MEEDER ASSET MANG. } & $\$ 0.216$ \\
\hline 121 & & SUMMIT INV. PARTNERS I & & $\$ 0.175$ \\
\hline 122 & & ZIEGLER CAPITAL MANG. & & $\$ 0.174$ \\
\hline 123 & & RE ADVISERS & & $\$ 0.173$ \\
\hline 124 & & FIRST FIN. CAPITAL ADVIS & & $\$ 0.171$ \\
\hline 125 & & CAPITAL ONE & & $\$ 0.162$ \\
\hline 126 & & CONSULTING GROUP CAP & KTS & $\$ 0.155$ \\
\hline 127 & & SUN CAPITAL & & $\$ 0.151$ \\
\hline 128 & & ADVANTUS & & $\$ 0.138$ \\
\hline 129 & & CHANGING PARAMETERS & & $\$ 0.135$ \\
\hline 130 & & PRUDENTIAL & & $\$ 0.131$ \\
\hline 131 & & FBR FUND ADVISERS & & $\$ 0.115$ \\
\hline 132 & & VINTAGE MUTUAL FUNDS & & $\$ 0.109$ \\
\hline 133 & & REGIONS/MORGAN KEEG & & $\$ 0.108$ \\
\hline 134 & & RAFFERTY ASSET MANG. & & $\$ 0.102$ \\
\hline 135 & & WIETZ FUNDS & & $\$ 0.095$ \\
\hline 136 & & BISHOP STREET CAPITAL & NG. & $\$ 0.094$ \\
\hline 137 & & NICHOLAS COMPANY & & $\$ 0.079$ \\
\hline 138 & & MANAGERS INV. GROUP & & $\$ 0.078$ \\
\hline 139 & & SIT INV. ASSOCIATES & & $\$ 0.071$ \\
\hline 140 & & SECURITY INVESTORS & & $\$ 0.067$ \\
\hline
\end{tabular}


Table 1 (continued)

\begin{tabular}{lll}
\hline & Fund sponsor & $\begin{array}{c}\text { Amount } \\
\text { insured in } \\
\text { billions }\end{array}$ \\
\hline 141 & & $\$ 0.055$ \\
142 & FRED ALGER MANG. & $\$ 0.047$ \\
143 & PACIFIC LIFE INSURANCE CO. & $\$ 0.038$ \\
144 & OLD MUTUAL CAPITAL & $\$ 0.028$ \\
145 & SARATOGA ADVANTAGE TRUST & $\$ 0.003$ \\
& KINETICS ASSET MANG. & $\$ 2721$ \\
\hline
\end{tabular}

This list was obtained from the author's Freedom of Information Act (FOIA) request number 2011-08-188. Most sponsors had multiple funds receiving taxpayer guarantees. Guaranteed amounts, when not provided in the FOIA request, were obtained from SEC filings or estimated from the CRSP mutual fund database. The last money market mutual fund guarantee extended by the U.S. Treasury expired on September $18,2009$. Readers may not use or reproduce any part of this list without citing this paper

definition of sponsor support, arguing that it is too broad and does not always apply to distressed funds. This is certainly the case. In Table 2, we see that in only about 1 in 6 of the cases (weighted by total assets) did sponsor support mean that a fund was actually rescued from breaking the buck. Yet, it is clear from Table 2 that many instances of sponsor support as defined by the SEC were also cases where money market mutual funds would have broken the buck without sponsor assistance. The SEC data in Hensler (2012) represent a unique data set that has not exposed to any empirical testing at the time of writing.

Brady et al. (2012) have a much narrower definition of "support" than the SEC study in Hensler (2012). Only cash gifts or below market purchases of securities constitute support in Brady et al. (2012). The authors of Brady et al. (2012) all worked at the Federal Reserve Bank of Boston. This "Boston Fed" study excludes insurance arrangements, puts, or letters of credit as support because they would be difficult to value. ${ }^{3}$ Clearly, this definition is too narrow because insurance must have some value, or otherwise no one would pay for it.

We use the narrow Boston Fed definition of support as well as the broader SEC definition of support in the present paper. Fund shares that received sponsor support as identified by Brady et al. (2012) between 2007 and September 18, 2009 , the end of the U.S. Treasury money market guarantee, are associated with a dummy variable equal to 1 . If the fund shares did not receive any sponsor support, the dummy variable is set to zero. In our sample of 1565 fund share classes, only 86 fund share classes were identified as having sponsor

\footnotetext{
3 The author reminds readers about the standard disclaimer that studies by employees of the Federal Reserve may not reflect the views of their bank or the Federal Reserve Board.
}

support, according to the Boston Fed study. This is the first study to empirically test the data in Brady et al. (2012). ${ }^{4}$

We also used the Boston Fed data to determine which funds would have broken the buck without sponsor support. Any fund receiving aggregate sponsor support greater than $0.5 \%$ of fund assets or $\$ 0.005$ per fund share from 2007 to September 18, 2009, is defined as "breaking the buck." Thus, the corresponding fund shares tracked by CRSP were coded as 1 if they had sponsor support sufficient to break the buck over this period. Otherwise, they were coded as zero. Only 57 fund-share classes out of 1565 broke the buck by this definition.

In Table 2, we aggregate the instances of sponsor support as defined by the SEC. The assets of the sponsor supported funds are listed as of September 30, 2008. Next, we aggregated the fund assets of funds receiving both U.S. Treasury guarantees and sponsor support as defined by the SEC. Then, we aggregate the assets of the funds receiving sponsor support as defined by both the Boston Fed and SEC. Finally, we aggregated the assets of funds receiving support under the SEC definition that would have broken the buck without sponsor support based on the Brady et al. (2012) data. The assets of money funds with sponsor support in 2007 or 2008 topped $\$ 700$ billion. Almost all of those funds were insured by taxpayers. Over $25 \%$ of the $\$ 2716$ billion in money fund assets insured by taxpayers were funds that the SEC believed were being propped up by their sponsors. The funds receiving cash support as defined by the Boston Fed accounted for just over $30 \%$ of the funds' assets defined as receiving support by the SEC. Only about 1 in 6 fund assets, \$114 billion out of $\$ 705$ billion, which are identified as receiving support by the SEC would have broken the buck. Of the

\footnotetext{
${ }^{4}$ The Moody's (2010) data are not used because that study does not name the sponsors and funds giving and receiving support, respectively.
} 
Table 2 Sponsor bailouts of money market mutual funds

\begin{tabular}{|c|c|c|c|c|c|}
\hline Rank & Fund sponsor & $\begin{array}{l}\text { Fund assets in billions } \\
\text { supported by sponsors }\end{array}$ & $\begin{array}{l}\text { Fund assets in billions } \\
\text { supported by sponsors and } \\
\text { insured by taxpayers }\end{array}$ & $\begin{array}{l}\text { Fund assets supported by } \\
\text { sponsors that received cash } \\
\text { subsidies from sponsors }\end{array}$ & $\begin{array}{l}\text { Fund assets supported by } \\
\text { sponsors that would have } \\
\text { broken the buck without } \\
\text { sponsor subsidies }\end{array}$ \\
\hline 1 & DREYFUS & $\$ 270.97$ & $\$ 267.04$ & $\$ 59.44$ & $\$ 12.21$ \\
\hline 2 & CHARLES SCHWAB & $\$ 91.41$ & $\$ 91.41$ & $\$ 0.00$ & $\$ 0.00$ \\
\hline 3 & COLUMBIA FUNDS & $\$ 59.44$ & $\$ 59.44$ & $\$ 59.44$ & $\$ 12.21$ \\
\hline 4 & MORGAN STANLEY & $\$ 57.13$ & $\$ 57.13$ & $\$ 16.39$ & $\$ 0.00$ \\
\hline 5 & LEGG MASON & $\$ 45.09$ & $\$ 45.09$ & $\$ 35.37$ & $\$ 35.37$ \\
\hline 6 & $\begin{array}{l}\text { EVERGREEN INV. } \\
\text { MANG. }\end{array}$ & $\$ 35.98$ & $\$ 35.98$ & $\$ 35.98$ & $\$ 35.98$ \\
\hline 7 & NORTHERN TRUST & $\$ 22.93$ & $\$ 22.93$ & $\$ 0.00$ & $\$ 0.00$ \\
\hline 8 & WELLS FARGO & $\$ 22.12$ & $\$ 22.12$ & $\$ 0.00$ & $\$ 0.00$ \\
\hline 9 & TD ASSET MANG. & $\$ 19.80$ & $\$ 19.80$ & $\$ 0.00$ & $\$ 0.00$ \\
\hline 10 & $\begin{array}{l}\text { VOYAGEUR ASSET } \\
\text { MANG. }\end{array}$ & $\$ 13.01$ & $\$ 13.01$ & $\$ 0.00$ & $\$ 0.00$ \\
\hline 11 & RIDGEWORTH FUNDS & $\$ 8.49$ & $\$ 8.49$ & $\$ 8.49$ & $\$ 8.49$ \\
\hline 12 & SEI GROUP & $\$ 7.07$ & $\$ 7.07$ & $\$ 7.07$ & $\$ 7.07$ \\
\hline 13 & CREDIT SUISSE & $\$ 6.66$ & $\$ 6.66$ & $\$ 0.00$ & $\$ 0.00$ \\
\hline 14 & ING & $\$ 6.03$ & $\$ 6.03$ & $\$ 0.00$ & $\$ 0.00$ \\
\hline 15 & RUSSELL INV. & $\$ 5.82$ & $\$ 5.82$ & $\$ 0.00$ & $\$ 0.00$ \\
\hline 16 & USAA INV. MANG & $\$ 5.72$ & $\$ 5.72$ & $\$ 0.00$ & $\$ 0.00$ \\
\hline 17 & RIVERSOURCE INV. & $\$ 4.75$ & $\$ 4.75$ & $\$ 0.00$ & $\$ 0.00$ \\
\hline 18 & $\begin{array}{l}\text { JANUS CAPITAL } \\
\text { MANG. }\end{array}$ & $\$ 4.16$ & $\$ 4.16$ & $\$ 0.00$ & $\$ 0.00$ \\
\hline 19 & $\begin{array}{l}\text { VICTORY CAPITAL } \\
\text { MANG. }\end{array}$ & $\$ 3.29$ & $\$ 3.29$ & $\$ 0.89$ & $\$ 0.00$ \\
\hline 20 & NEUBERGER BERMAN & $\$ 2.86$ & $\$ 0.00$ & $\$ 0.00$ & $\$ 0.00$ \\
\hline 21 & PRINCIPAL MANG. & $\$ 2.71$ & $\$ 0.70$ & $\$ 0.00$ & $\$ 0.00$ \\
\hline 22 & $\begin{array}{l}\text { PHOENIX INV.PART- } \\
\text { NERS }\end{array}$ & $\$ 2.55$ & $\$ 2.55$ & $\$ 2.46$ & $\$ 2.46$ \\
\hline 23 & $\begin{array}{l}\text { NATIONWIDE FUND } \\
\text { ADV. }\end{array}$ & $\$ 2.44$ & $\$ 2.44$ & $\$ 0.00$ & $\$ 0.00$ \\
\hline 24 & $\begin{array}{l}\text { MUNDER CAPITAL } \\
\text { MANG. }\end{array}$ & $\$ 1.92$ & $\$ 1.92$ & $\$ 0.00$ & $\$ 0.00$ \\
\hline 25 & $\begin{array}{l}\text { THRIVENT FIN. FOR } \\
\text { LUTHERANS }\end{array}$ & $\$ 1.54$ & $\$ 1.54$ & $\$ 0.00$ & $\$ 0.00$ \\
\hline 26 & $\begin{array}{l}\text { TCW INV. MANG. COM- } \\
\text { PANY }\end{array}$ & $\$ 0.85$ & $\$ 0.85$ & $\$ 0.00$ & $\$ 0.00$ \\
\hline \multirow[t]{2}{*}{27} & $\begin{array}{l}\text { GOLDMAN SACHS \& } \\
\text { CO. }\end{array}$ & $\$ 0.25$ & $\$ 0.25$ & $\$ 0.00$ & $\$ 0.00$ \\
\hline & Total & $\$ 705.0$ & $\$ 696.2$ & $\$ 225.5$ & $\$ 113.8$ \\
\hline
\end{tabular}

All assets numbers are in billions and are from September 30, 2008. The asset figures are taken from the CRSP mutual fund database. Funds sponsors are ranked by the assets of funds which received support from their sponsors in 2007 to 2008 according to the SEC definition in Hensler (2012). Approximately $25 \%$ of the $\$ 2716$ billion in fund assets guaranteed by taxpayers were from fund that the SEC identified as having sponsor support, according to our estimates. Brady et al. (2012) was the source for cash support by sponsors during the crisis defines sponsor support very narrowly as cash injections that represent subsidies to the particular funds. Brady et al. (2012) does not include guarantees in their definition of sponsor support. Funds saved from breaking the buck received support, as defined by Brady et al. (2012), which exceeded 0.5\% of fund assets. Highlighted fund sponsors saved $100 \%$ of fund assets tracked by CRSP from breaking the buck. Readers may not use or reproduce any part of this list without citing this paper

27 fund sponsors identified by the SEC as supporting their funds during the financial crisis, only 7 provided cash support sufficient to prevent the funds from breaking the buck between 2007 and September 18, 2009, the end of the U.S. Treasury's Money Market Mutual Fund Guarantee program. Nevertheless, however, we slice this data, money funds were 
riskier during the financial crisis of 2007-to-2009 than is suggested by only one money fund breaking the buck, during this time of stress. Sponsor support masked many of the risks of money funds.

Moreover, the instances where sponsors provided letters of credit, puts, guarantees, and other forms of insurance but never provided cash payouts likely prevented some more funds from breaking the buck. These actions likely eased institutional investors' concerns about those funds and prevented liquidity crises that could have caused these sponsor-assisted funds to break the buck. In the same way, the explicit taxpayer guarantee of up to $\$ 2.7$ trillion of money market mutual funds assets from September 19, 2008, to September 18, 2009, likely prevented additional money funds from breaking the buck during the crisis.

The Dodd-Frank Wall Street Reform and Consumer Protection Act of 2010 required the Federal Reserve to disclose its emergency lending programs during the 2007-to2009 financial crisis in December 2010. Money funds were directly benefited by the Asset-Backed Commercial Paper Money Market Liquidity Facility (AMLF), which financed the purchase of asset-backed commercial paper directly from money funds. Pavlov and Wachter (2002, 2009a, b), Wilson $(2011,2012)$ discuss how underpriced non-recourse loans used in the Fed's emergency lending programs can boost asset prices. Duygan-Bump et al. (2013) looks at three characteristics of money funds that participated in that program. Nevertheless, that study does not look at how AMLF participation is correlated with participation in the U.S. Treasury's guarantee or sponsor support of money funds. The author matched the money funds selling $\mathrm{ABCP}$ in that program by hand to money fund share classes in our sample. There were 387 mutual fund share classes in this sample that participated in the AMLF program.

Our final source of data was iMoneynet which tracks money market mutual fund holdings. We found the percent holdings of the money market mutual fund share classes in lower rated second-tier commercial paper and auction rate securities. In addition, iMoneynet provided data on the percent of assets maturing in the next 7 days.

\section{The $\mathbf{2 0 1 0}$ money market reforms}

This paper attempts to test if the 2010 money market reforms enacted by the SEC would have prevented past instances of sponsor support of money funds or the 2008 bailout of the money market mutual fund industry. In early 2010 , the SEC enacted five quantifiable new requirements as discussed in Federal Register (2010) for rule 2a-7 money market funds, which maintain a stable price at $\$ 1.00$. All five of these new requirements will be tested in this paper.
1 Daily Liquid Assets (DLA): Money market funds had to have $10 \%$ of their assets in assets daily liquid assets. These assets are defined as cash, demand deposits, U.S. Treasury securities, and overnight repos collateralized by U.S. Treasury securities.

2 Weekly Liquid Assets (WLA): Money market funds have to have $30 \%$ of their portfolio in weekly liquid assets. These include daily liquid assets plus securities that the fund has a right to receive cash in 5 business days. In addition, U.S. government agency securities of 60 days or less are included in this definition.

3 Weighted Average Maturity (WAM): Rule 2a-7 was amended requiring money funds to decrease their weighted average maturity from less than 90 days to less than 60 days.

4 Second Tier Commercial Paper (STCP): Rule 2a-7 was amended to require that money funds reduce their holding of lower quality, and riskier, second tier commercial paper. The old standard required that funds hold no more than 5\% of assets in second tier commercial paper. The 2010 standard limited second tier commercial paper to $3 \%$ of total assets.

5 Weighted Average Life (WAL): This new requirement said that the fund assets could not have a weighted average life greater than 120 days. This requirement penalizes funds which have a lot of assets in auction rate or floating-rate securities which have long maturities but are repeatedly auctioned to new investors. The auction dates, not the final maturities of these securities are used in calculating weighted average maturity (WAM). Thus, this measure discourages money funds from holding these floating-rate notes. Han and Li (2010), Liu et al. (2010), and McConnell and Saretto (2010) detail how many of these floating-rate auctions failed in the months prior September 2008, leaving money fund investors stuck holding these securities for time periods much longer than originally intended.

This paper uses several proxies for the five new standards. Yet, these proxies are imperfect because the best data available from iMoneynet did not precisely track these definitions in 2008. Instead, iMoneynet had data on the percent holdings in various categories, the percent of securities maturing in 7 days, and the weighted average maturity (WAM) of the fund share assets.

To find the proxy of the daily liquid assets standard, the sum of the following items in September 2008 was calculated:

Sum DLA $=\%$ Treasuries $+\%$ Repos $+\%$ Domestic Bank Deposits $+\%$ Foreign Bank Deposits

To avoid double counting the safe securities in Sum DLA, the dummy variable for the DLA standard would equal 
Table 3 Summary statistics

\begin{tabular}{|c|c|c|c|c|c|c|}
\hline Variable & Average & Median & SD & 90th percentile & 10th percentile & Number of obs. \\
\hline \multicolumn{7}{|c|}{ Panel A: Data items related to the new SEC regulations enacted in 2010 for money market mutual funds } \\
\hline $\begin{array}{l}\text { Adhered to } 2010 \text { SEC reforms' daily liquidity standard in } \\
\text { September } 2008(Y=1, N=0)\end{array}$ & 0.885 & 1 & 0.319 & 1 & 0 & 1416 \\
\hline $\begin{array}{l}\text { Adhered to } 2010 \text { SEC reforms' weekly liquidity standard in } \\
\text { September } 2008(Y=1, N=0)\end{array}$ & 0.976 & 1 & 0.154 & 1 & 1 & 1492 \\
\hline $\begin{array}{l}\text { Adhered to } 2010 \text { SEC reforms' WAM standard in September } \\
2008(\mathrm{Y}=1, N=0)\end{array}$ & 0.914 & 1 & 0.280 & 1 & 1 & 1399 \\
\hline $\begin{array}{l}\text { Adhered to } 2010 \text { SEC reforms' second-tier commercial paper } \\
\text { standard in September } 2008(Y=1, N=0)\end{array}$ & 0.999 & 1 & 0.037 & 1 & 1 & 1456 \\
\hline Second-tier commercial paper as \% of AUM & 0.013 & 0 & 0.230 & 0 & 0 & 1456 \\
\hline $\begin{array}{l}\text { Weighted average life (WAL) proxy, floating-rate notes as \% } \\
\text { of AUM }\end{array}$ & 10.606 & 1 & 14.640 & 33 & 0 & 1456 \\
\hline \multicolumn{7}{|c|}{ Panel B: Data items related to taxpayer and sponsor rescues of money market mutual funds during the 2007-to-2009 financial crisis } \\
\hline Accepted U.S. Treasury guarantee $(\mathrm{Y}=1, N=0)$ & 0.910 & 1 & 0.286 & 1 & 1 & 1565 \\
\hline September $19,2008, \mathrm{NAV}<\$ 0.9975(\mathrm{Y}=1, N=0)$ & 0.105 & 0 & 0.306 & 1 & 0 & 1414 \\
\hline $\begin{array}{l}\text { Participated in Federal Reserve's Asset-Backed Commercial } \\
\text { Paper Money Market Liquidity Facility (AMLF) }(Y=1, N \\
=0)\end{array}$ & 0.247 & 0 & 0.432 & 1 & 0 & 1565 \\
\hline $\begin{array}{l}\text { Sponsor prevented fund from breaking the buck during the } \\
\text { financial crisis }(Y=1, N=0)\end{array}$ & 0.036 & 0 & 0.187 & 0 & 0 & 1565 \\
\hline $\begin{array}{l}\text { Sponsor injected money into the fund during the financial } \\
\text { crisis }(Y=1, N=0)\end{array}$ & 0.055 & 0 & 0.228 & 0 & 0 & 1565 \\
\hline $\begin{array}{l}\text { Sponsor supported the fund according to the } \operatorname{SEC}(Y=1, N \\
=0)\end{array}$ & 0.204 & 0 & 0.403 & 1 & 0 & 1565 \\
\hline \multicolumn{7}{|l|}{ Panel C: Hypothesis 3 and control variables } \\
\hline Institutional fund $(Y=1, N=0)$ & 0.582 & 1 & 0.493 & 1 & 0 & 1565 \\
\hline Prime fund $(Y=1, N=0)$ & 0.467 & 0 & 0.499 & 1 & 0 & 1565 \\
\hline Prime and institutional fund $(Y=1, N=0)$ & 0.250 & 0 & 0.433 & 1 & 0 & 1565 \\
\hline Municipal or tax-free fund $(Y=1, N=0)$ & 0.171 & 0 & 0.377 & 1 & 0 & 1565 \\
\hline U.S. government fund $(Y=1, N=0)$ & 0.199 & 0 & 0.399 & 1 & 0 & 1565 \\
\hline U.S. Treasury fund $(Y=1, N=0)$ & 0.163 & 0 & 0.369 & 1 & 0 & 1565 \\
\hline Fund assets in billions & $\$ 1.956$ & $\$ 0.271$ & $\$ 5.902$ & $\$ 5.075$ & $\$ 0.003$ & 1565 \\
\hline $\begin{array}{l}\text { Natural log of one plus assets under management in USD } \\
\text { billions }\end{array}$ & 0.586 & 0.240 & 0.785 & 1.804 & 0.003 & 1565 \\
\hline $\begin{array}{l}\text { Fund age in years at the start of the U.S. Treasury money fund } \\
\text { guarantee }\end{array}$ & 11.168 & 9.715 & 7.964 & 23.108 & 1.756 & 1565 \\
\hline Monthly return in September 2008 & $0.145 \%$ & $0.150 \%$ & $0.045 \%$ & $0.200 \%$ & $0.090 \%$ & 1561 \\
\hline Share class expense ratio in September 2008 & $0.586 \%$ & $0.510 \%$ & $0.377 \%$ & $1.048 \%$ & $0.200 \%$ & 1503 \\
\hline $\begin{array}{l}\text { Change in fund's assets under management (AUM) from Sep- } \\
\text { tember 12, } 2008 \text { to September 18, } 2008\end{array}$ & $1.604 \%$ & $-0.395 \%$ & $26.767 \%$ & $28.752 \%$ & $-28.830 \%$ & 1392 \\
\hline Fund's yield in September 2008 & $0.601 \%$ & $0.490 \%$ & $0.438 \%$ & $1.257 \%$ & $0.300 \%$ & 1564 \\
\hline
\end{tabular}

Assets and portfolio holdings are as of September 30, 2008

one if Sum DLA + (1/7) (\% Maturing in 7 Days) $(1-$ Sum DLA) $\geq 10 \%$.

The weekly liquid assets standard was calculated first by summing the following:

Sum WLA $=\%$ Treasuries $+\%$ Repos $+\%$ Domestic Bank Deposits $+\%$ Foreign Bank Deposits + (2/3) (\%U.S. Agency Securities) ( $\{$ minimum 60/WAM, 1$\})$
The calculation of U.S. government agency securities reflects the fact that the weighted average maturity declined after the 2010 reforms took effect. The weekly liquid assets (WLA) dummy equaled 1 if (Sum WLA) $+(\%$ Maturing in 7 Days) (1 - Sum WLA) $\geq 30 \%$.

The third and fourth standards were easy to measure with 2008 data. iMoneynet did track WAM in days. Thus, the 2010 weighted average liquidity standard was satisfied if $\mathrm{WAM} \leq 60.99 .9 \%$ of the funds had less than $3 \%$ of assets 
in second-tier commercial paper in September 2008. Thus, almost all funds adhered to the 2010 standard in 2008. The 2010s tier commercial paper standard dummy equaled 1 if $\%$ Second Tier Commercial Paper $\leq 3 \%$. Because there was so little variation in the data with respect to the second-tier commercial paper dummy, we also will look at the fund share's percent holdings of second-tier commercial paper.

The fifth new standard which is tested here is the weighted average life (WAL) standard. For this standard, the proxy for a fund-shares exposure to greater WAL is measured by its percent holdings in floating-rate notes.

Table 3, Panel A, presents the summary statistics for measures of whether or not funds were complying with the 2010 reforms in 2008. According to this paper's definition, $88.5 \%$ of funds would have met the 2010 daily liquidity standard in September 2008. Similarly, $97.6 \%$ of funds had weekly liquidity greater than $30 \%$. In the month that the Reserve Primary Fund broke the buck, $91.4 \%$ of funds had weighted average maturities of less than 60 days. Finally, $99.9 \%$ of fund had less than $3 \%$ of holdings in second-tier commercial paper. Thus, for these four standards, the vast majority of money funds were already in compliance before the 2010 reforms were proposed. Very few funds had any exposure to second-tier commercial paper in September 2008. Indeed, over $90 \%$ of fund shares had no exposure to second-tier commercial paper. Holdings of floating-rate notes were on average $10.6 \%$ of fund share assets. Larger holdings of floating-rate notes should be positively correlated with larger WAL.

In Table 3, panel B, the summary statistics for various types of money fund bailouts are presented. These six variables are dummy variables tracking fund shares' participation in taxpayer or sponsor bailouts during the financial crisis. In the sample, $91 \%$ of the fund shares participated in the taxpayers' money market mutual fund guarantee program. A subset of the fund shares participating in the guarantee program paid 1.5 basis points to the U.S. Treasury because their fund shares had floating net asset values at or above $\$ 0.995$ per share but below $\$ 0.9975$ per share on September 19,2008 . About $10.5 \%$ of the sample both participated in the U.S. Treasury guarantee and paid the higher insurance rate. About a quarter of the sample sold asset-backed commercial paper to buyers in Federal Reserve financed transactions in the AMLF program. 3.6\% of sample fund shares was saved from breaking the buck during the financial crisis because of cash rescues from their sponsors. Over $20 \%$ of the sample received some sort of assistance from their sponsors according to the SEC. Yet, much of that assistance was in the form of guarantees, insurance, or letters of credit.

The next six dummy variables summarize the styles of the fund shares in the sample. These were based on the Lipper classification codes for the funds. $58 \%$ of fund shares classes focused on institutional as opposed to retail investors. About half the money fund share classes were in prime funds. A quarter of the sample consisted of prime, institutional funds, which experienced the severe run after the Lehman Brothers bankruptcy filing. 17\% of the sample tracked tax-free municipal funds. $20 \%$ of funds bought securities of government sponsored entities such as Ginnie Mae, Fannie Mae, and Freddie Mac. Another 16\% of funds focused on U.S. Treasury securities.

Average total assets were almost $\$ 2$ billion although the median assets under management were $\$ 271$ million. The monthly returns in September 2008 were typically about 15 basis points. Yet, expense ratios were close to 59 basis points on average. The average fund saw its assets grow by almost $7 \%$ from the end of July 2009, to the end of September 2008. The mean yield of fund shares in the sample was about 60 basis points.

\section{Hypotheses}

In this section, we develop hypotheses regarding fund shares that received taxpayer guarantees from beginning in September 19, 2008, and funds that received sponsor assistance in 2007 to 2008, based on the SEC study in Hensler (2012).

The first set of hypotheses tests if the 2010 reforms could have prevented the sponsor and taxpayer bailouts in the financial crisis of 2008.

\section{Hypothesis 1 (2010 reforms)}

(a) Money market funds with daily liquid assets (DLA) greater than $10 \%$ are less likely to be bailed out by taxpayers or their sponsors.

(b) Money market funds with weekly liquid assets (WLA) greater than $30 \%$ are less likely to be bailed out by taxpayers or their sponsors.

(c) Money market funds with weighted average maturities (WAM) less than 60 days are less likely to be bailed out by taxpayers or their sponsors.

(d) Money funds with a lower percentage of second-tier commercial paper are less likely to receive taxpayer or sponsor bailouts.

(e) Money funds with lower percentages of floating-rate securities, a proxy for the weighted average life (WAL) limits, will be less likely to receive taxpayer or sponsor bailouts.

The second set of hypotheses test if bailouts are compliments or substitutes: 


\section{Hypothesis 2 (bailouts as complements)}

(a) Funds that receive bailouts from taxpayers are significantly more likely to have been bailed out by the Fed or their sponsors.

(b) Funds that are bailed out by their sponsors are significantly more likely to receive bailouts from the Fed and U.S. Treasury.

It is not clear that bailouts complement one another. Wilson et al. (2014) finds a negative association between investment banks' borrowing from the Federal Reserve's Term Securities Lending Facility (TSLF) and the receipt of Troubled Asset Relief Program (TARP) capital injections. Yet, Wilson and $\mathrm{Wu}(2017,2018)$ find that there is a significant positive association between receiving TARP funds and selling commercial paper to the Federal Reserve through the Commercial Paper Financing Facility (CPFF) and receiving debt guarantees from the Federal Deposit Insurance Corporation (FDIC).

\section{Hypothesis 3 (fund styles and the 2014 floating NAV reforms)}

(a) Institutional money funds will be significantly more likely to receive taxpayer bailouts or bailouts from their sponsors.

(b) Prime money funds will be significantly more likely to receive taxpayer bailouts or bailouts from their sponsors.

(c) Municipal money funds will be significantly more likely to receive taxpayer bailouts or bailouts from their sponsors.

We know that the commercial paper default of Lehman Brothers exposed primarily the risks of investing in prime money market funds which were heavily exposed to financial commercial paper. The runs on prime money funds were primarily concentrated in the institutional, not the retail, fund sector. We would expect that taxpayer guarantees and sponsor support would be needed more for institutional money funds than retail money funds. Since SEC (2014) imposed floating NAV on municipal funds, the paper tests hypothesis $3 \mathrm{c}$ to see if those funds were more likely to be bailed out. Hypothesis 3 tests the 2014 money market reforms in SEC (2014) were first published in the Federal Register on October 14, 2014, and were made permanent two years later in 2016.

Those reforms among other things required floating NAV for institutional prime and municipal money market mutual funds. If the hypothesis is confirmed, then that would support the floating NAV rules as preventing future bailouts of MMMFs. SEC (2014) required rounding to the fourth decimal place (for example $\$ 1.0000$ ) as opposed to the second (for example \$1.00) as before.

The floating NAV requirement has lessened the incentive for runs when assets values dropped between $\$ 0.9950$ and $\$ 1.0000$ per share. If the shares are priced at $\$ 1.00$ due to rounding to the nearest penny, then savvy investors can make money selling their shares which are worth between and inclusive of $\$ .9950$ and $\$ 0.9999$, creating a run out of a fund.

\section{Participation in the U.S. Treasury's temporary guarantee for money market mutual funds}

In Table 4, the means of the fund share classes that received the U.S. Treasury's guarantees are compared to the means of fund share classes that did not receive taxpayer insurance. Surprisingly, funds that met the 2010 reforms' daily liquidity, weekly liquidity, and weighted average maturity standards were significantly more likely to obtain the taxpayer bailout. Far from these higher standards' preventing funds from getting taxpayer assistance, it appears that these more liquid funds with quicker maturing assets were more likely to obtain taxpayer insurance. The only part of hypothesis 1 that can be confirmed is that funds more exposed to risky, floating-rate notes, auction rate securities were more likely to participate in the TTGMMMF. Thus, the 2010 reforms' WAL standard could have prevented some funds from relying on taxpayer guarantees. Floating-rate notes are longer maturity assets more subject to interest rate and credit risk than other money market assets. It is not surprising that accepting a bailout was positively associated with higher levels of theses holdings. The new WAL regulation may be able to prevent future money fund bailouts.

Funds that receive the Fed's AMLF bailout or a sponsor bailout were significantly more likely to be bailed out by taxpayers. There is little evidence that institutional funds were more likely to obtain taxpayer guarantees despite their greater propensity toward runs during the financial crisis. Prime funds were significantly more likely to receive taxpayer guarantees and funds invested in U.S. government agency securities were significantly less likely to receive the U.S. Treasury's bailout guarantee. Larger, older, and higher expense ratio funds were also significantly more likely to benefit from U.S. Treasury guarantees.

Not all the univariate results about participation in the U.S. Treasury's Temporary Guarantee of Money Market Mutual Funds hold when we control for the influence of multiple factors. The logistic model can be used to estimate the probability that a given fund will receive a taxpayer bailout. Funds that get taxpayer guarantees have a dependent 
Table $4 t$-test of means of mutual fund share classes that participated in the taxpayer guarantee $(Y=1)$ and share classes that did not $(Y=0)$ participate in the taxpayer guarantee

\begin{tabular}{|c|c|c|c|c|c|c|}
\hline Variable & Mean when $Y=1$ & Mean when $Y=0$ & Difference & $t$-stat. & $\begin{array}{l}\text { Number of } \\
Y=1 \text { Obs. }\end{array}$ & $\begin{array}{l}\text { Number of } \\
Y=0 \text { Obs. }\end{array}$ \\
\hline $\begin{array}{l}\text { Adhered to } 2010 \text { SEC reforms' daily liquidity stand- } \\
\text { ard in September } 2008(Y=1, N=0)\end{array}$ & 0.860 & 0.757 & 0.103 & $3.213 * * *$ & 1337 & 136 \\
\hline $\begin{array}{l}\text { Adhered to } 2010 \text { SEC reforms' weekly liquidity } \\
\text { standard in September } 2008(Y=1, N=0)\end{array}$ & 0.948 & 0.752 & 0.196 & $8.948 * * *$ & 1424 & 141 \\
\hline $\begin{array}{l}\text { Adhered to } 2010 \text { SEC reforms' WAM standard in } \\
\text { September } 2008(Y=1, N=0)\end{array}$ & 0.923 & 0.827 & 0.096 & $3.706 * * *$ & 1227 & 127 \\
\hline $\begin{array}{l}\text { Adhered to } 2010 \text { SEC reforms' second-tier com- } \\
\text { mercial paper standard in September } 2008(Y=1 \text {, } \\
N=0)\end{array}$ & 0.999 & 1.000 & -0.001 & -0.447 & 1324 & 132 \\
\hline Second-tier commercial paper as $\%$ of AUM & 0.014 & 0.000 & 0.014 & 0.684 & 1324 & 132 \\
\hline $\begin{array}{l}\text { Weighted average life (WAL) proxy, floating-rate } \\
\text { notes as \% of AUM }\end{array}$ & 10.865 & 8.008 & 2.857 & $2.141 * *$ & 1324 & 132 \\
\hline $\begin{array}{l}\text { Participated in Federal Reserve's Asset-Backed } \\
\text { Commercial Paper Money Market Liquidity Facil- } \\
\text { ity (AMLF) }(Y=1, N=0)\end{array}$ & 0.258 & 0.142 & 0.116 & $3.049 * * *$ & 1424 & 141 \\
\hline $\begin{array}{l}\text { Sponsor prevented fund from breaking the buck dur- } \\
\text { ing the financial crisis }(Y=1, N=0)\end{array}$ & 0.040 & 0.000 & 0.040 & $2.423 * *$ & 1424 & 141 \\
\hline $\begin{array}{l}\text { Sponsor injected money into the fund during the } \\
\text { financial crisis }(Y=1, \mathrm{~N}=0)\end{array}$ & 0.060 & 0.000 & 0.060 & $3.009 * * *$ & 1424 & 141 \\
\hline $\begin{array}{l}\text { Sponsor supported the fund according to the SEC ( } Y \\
\quad=1, N=0 \text { ) }\end{array}$ & 0.211 & 0.142 & 0.069 & $1.934 *$ & 1424 & 141 \\
\hline Institutional fund $(Y=1, N=0)$ & 0.574 & 0.667 & -0.093 & $-2.136^{* *}$ & 1424 & 141 \\
\hline Prime fund $(Y=1, N=0)$ & 0.485 & 0.291 & 0.194 & $4.424 * * *$ & 1424 & 141 \\
\hline Prime and institutional fund $(Y=1, N=0)$ & 0.254 & 0.206 & 0.049 & 1.270 & 1424 & 141 \\
\hline Municipal or tax-free fund $(Y=1, N=0)$ & 0.176 & 0.128 & 0.048 & 1.440 & 1424 & 141 \\
\hline U.S. government fund $(Y=1, N=0)$ & 0.179 & 0.397 & -0.218 & $-6.264 * * *$ & 1424 & 141 \\
\hline U.S. Treasury fund $(Y=1, N=0)$ & 0.161 & 0.184 & -0.024 & -0.723 & 1424 & 141 \\
\hline $\begin{array}{l}\text { Natural log of one plus assets under management in } \\
\text { USD billions }\end{array}$ & 0.621 & 0.234 & 0.387 & $5.636 * * *$ & 1424 & 141 \\
\hline $\begin{array}{l}\text { Fund age in years at the start of the U.S. Treasury } \\
\text { money fund guarantee }\end{array}$ & 11.557 & 7.243 & 4.314 & $6.209 * * *$ & 1424 & 141 \\
\hline Monthly return in September 2008 & $0.145 \%$ & $0.143 \%$ & $0.002 \%$ & 0.526 & 1420 & 141 \\
\hline Share class expense ratio in September 2008 & $0.595 \%$ & $0.493 \%$ & $0.102 \%$ & $2.946 * * *$ & 1374 & 129 \\
\hline $\begin{array}{l}\text { Change in fund's assets under management (AUM) } \\
\text { from September 12, } 2008 \text { to September 18, } 2008\end{array}$ & $1.722 \%$ & $-0.124 \%$ & $1.846 \%$ & $7.376^{* * *}$ & 1268 & 125 \\
\hline Fund's yield in September 2008 & $0.598 \%$ & $0.618 \%$ & $-0.020 \%$ & -0.505 & 1423 & 141 \\
\hline
\end{tabular}

AUM stands for assets under management. Statistical significances with 99, 95, and 90\% confidence are denoted by $t$-statistics with superscripts of $* * *, * *$, and $*$, respectively

variable equal to 1 , and those that do not have a dependent variable equal to 0 .

The proxy for the weighted average life (WAL) 2010 reform is still significant. More exposure to floating-rate securities which increase a fund's weighted average life is positively associated with fund shares being guaranteed by taxpayers. In addition, the compliance with the weighted average maturity (WAM) standard is significant and of the predicted sign in most specifications. Therefore, it seems holding longer maturity assets more subject to interest rate and credit risk is positively associated with a money fund getting bailed out. The WAL and WAM regulations limit money funds from sneaking in longer maturity assets in pursuit of yield. All the other variables, which are proxies for the 2010 standards, are insignificant in some specifications or are significant but have the opposite of their predicted sign. For example, funds that exceeded the $30 \%$ liquidity threshold were significantly more likely to be bailed out.

The funds benefitting from the Fed's AMLF bailout were more likely to get U.S. Treasury guarantees. Yet, funds with sponsor assistance as defined by the SEC were significantly less likely to get taxpayer guarantees after controlling for 
other factors. In addition, funds receiving only cash assistance under the Boston Fed's definition of a sponsor bailout were no more likely to participate in the TTGMMMF.

Several other coefficients retain their sign and significance when controlling for other factors. Larger funds are more likely to get taxpayer guarantees. Prime funds and older funds are more likely to use the taxpayer insurance. Interestingly, the institutional dummy was insignificant in most regressions. Thus, the SEC's (2014) reform, SEC (2014), requiring only prime institutional money funds to have a floating NAV may be too narrow. All prime funds, both retail and institutional, were more likely to be bailed out. With a floating NAV, the incentive for runs and need for bailouts are greatly reduced since there is no benefit to getting to the exits first.

Funds which experienced net inflows during the week when the Reserve Primary Fund broke the buck were more likely to obtain taxpayer guarantees. Thus, the most troubled funds, with net outflows, were significantly less likely to benefit from the TTGMMMF.

\section{Sponsor bailouts of Money Market Mutual Funds in 2007-2008}

In this section, we look at the associations between fund characteristics and the propensity of the fund shares to obtain a sponsor bailout as defined by the SEC. Unlike the Treasury program, which had $91 \%$ participation among our sample, only 320 fund share classes of 1565 in our sample received assistance from their sponsors during the financial crisis, according to Hensler (2012). Of those 320 fundshare classes with sponsor bailouts, 300 fund-share classes sampled also received taxpayer guarantees. Thus, taxpayers aided the vast majority of funds that their sponsors felt compelled to assist.

Only some of the SEC's 2010 money market reforms were associated with a lower propensity to need sponsor support. The $t$-tests only support s hypotheses $1 \mathrm{c}$ and $1 \mathrm{e}$ regarding the effectiveness of the new weighted average maturity (WAM) and weighted average life (WAL) standards. Funds were significantly less likely to receive sponsor bailouts if they had lower weighted average maturities in September 2008. They were more likely to need sponsor bailouts if they had auction rate securities with longer WAL. These results are similar to Table 4 . Thus, the reforms that would have been the most likely to lessen the need for taxpayer and sponsor bailouts in the 2008 financial crisis were the WAM and WAL reforms.

In Table 6, we find that fund shares assisted by their sponsors, according to Hensler (2012), were significantly more likely to get bailouts from the Federal Reserve, direct cash assistance from sponsors during the financial crisis and help from taxpayers. Moreover, the fund shares that paid the higher insurance rates for the taxpayer bailout because they were close to breaking the buck were significantly more likely to receive sponsor support, according to the SEC.

The funds with sponsor bailouts tended to cater to institutional investors. Prime funds were significantly more likely to get a sponsor bailout; while municipal, U.S. government, and U.S. Treasury funds were significantly less likely to receive sponsor bailouts. In contrast to funds with taxpayer assistance, funds with sponsor bailouts were significantly younger, with smaller expense ratios and had significantly more outflows during the Lehman Brother's bankruptcy week.

In Table 7, multivariate logit regressions were run. Positive coefficients indicate that increases in the independent variable make it more likely that fund shares will be bailed out by the fund sponsor. There was too little variation in the data with respect to second-tier commercial paper holdings to test hypothesis $1 \mathrm{~d}$ in Table 7 , but the rest of the 2010 money market reforms in hypothesis 1 were tested after controlling for other factors. Only the WAM standard seemed to make sponsor bailouts less likely. After controlling for other factors, the DLA, WLA, and WAL reforms had either an insignificant coefficient or the opposite of the predicted sign.

Funds with U.S. Treasury guarantees with a September 19,2008 , NAV at or above $\$ 0.995$ and below $\$ 0.9975$ were significantly more likely to receive sponsor bailouts. In addition, funds participating in the Fed's asset-backed commercial paper purchase program were also more likely to get sponsor help during the 2007 to 2008 financial crisis after controlling for other factors. Institutional funds and funds with higher monthly returns in September 2008 were more likely to get sponsor assistance after controlling for other factors.

Yet, most of the other results that were significant in the $t$-tests lost their significance or the sign changed when we controlled for other factors in the logistic specification. For example, fund outflows in the week when the Reserve Primary Fund broke the buck were not significantly related to sponsor bailouts.

Moreover, the 2014 floating NAV reforms focus on muni or prime funds finds no support in Table 7. Those fund styles were not significantly more likely to be bailed out by their sponsors, rejecting hypotheses $3 \mathrm{~b}$ and $3 \mathrm{c}$. Thus, those fund styles were more likely to be bailed out by taxpayers (in Table 5) but not by their sponsors (in Table 7). A similar mixed support for SEC (2014)'s floating NAV can be found with respect to institutional funds, hypothesis $3 \mathrm{a}$. Institutional funds were significantly more likely to be bailed out by sponsors (in Table 7), but not significantly more likely to be bailed out by taxpayers (in Table 5). 
Table 5 Logistic regressions of a fund share classes' participation in the U.S. Treasury's guarantee of money market mutual funds

The dependent variable equals 1 if the fund shares participated in the U.S. Treasury guarantee program and 0 otherwise

\begin{tabular}{|c|c|c|c|c|c|}
\hline \multirow[b]{2}{*}{ Independent variable } & \multicolumn{4}{|l|}{ Coefficients } & \multirow{2}{*}{$\begin{array}{l}\text { Pred. } \\
\text { Sign }\end{array}$} \\
\hline & Model 1 & Model 2 & Model 3 & Model 4 & \\
\hline $\begin{array}{l}\text { Adhered to } 2010 \text { SEC reforms' daily liquidity standard in September } 2008(Y=1, N= \\
\text { 0) }\end{array}$ & -0.556 & -0.082 & -0.118 & & - \\
\hline $\begin{array}{l}\text { Adhered to } 2010 \text { SEC reforms' weekly liquidity standard in September } 2008(Y=1, N \\
=0)\end{array}$ & $4.327 * * *$ & $3.991 * * *$ & $4.167 * * *$ & $4.139 * * *$ & - \\
\hline Adhered to 2010 SEC reforms' WAM standard in September $2008(Y=1, \mathrm{~N}=0)$ & -0.911 & $-1.069 *$ & -0.997 & $-1.008 *$ & - \\
\hline Second-tier commercial paper as \% of AUM & 11.210 & 11.077 & 11.199 & & + \\
\hline Weighted average life (WAL) proxy, floating-rate notes as \% of AUM & 0.015 & $0.039 * * *$ & $0.029 * *$ & $0.029 * *$ & + \\
\hline $\begin{array}{l}\text { Participated in Federal Reserve's Asset-Backed Commercial Paper Money Market } \\
\text { Liquidity Facility (AMLF) }(\mathrm{Y}=1, N=0)\end{array}$ & $0.997 * *$ & 0.579 & $0.993 * *$ & & + \\
\hline $\begin{array}{l}\text { Sponsor prevented fund from breaking the buck during the financial crisis }(Y=1, \mathrm{~N}= \\
0)\end{array}$ & & & 36.187 & & + \\
\hline Sponsor injected money into the fund during the financial crisis $(Y=1, \mathrm{~N}=0)$ & & 38.715 & & & + \\
\hline Sponsor supported the fund according to the $\operatorname{SEC}(Y=1, \mathrm{~N}=0)$ & $-0.087 *$ & & & & + \\
\hline Institutional fund $(Y=1, N=0)$ & 0.063 & -0.001 & $0.702 * *$ & 0.119 & + \\
\hline Prime fund $(Y=1, N=0)$ & $1.137 * *$ & $2.942 * * *$ & $2.703 * * *$ & $2.729 * * *$ & + \\
\hline Municipal or tax-free fund $(\mathrm{Y}=1, N=0)$ & & $2.757 * * *$ & $2.567 * * *$ & $2.597 * * *$ & - \\
\hline U.S. government fund $(Y=1, N=0)$ & $-0.025 * * *$ & -0.007 & -0.007 & -0.007 & - \\
\hline Natural log of one plus assets under management in USD billions & & & $0.702 * *$ & $0.700 * *$ & + \\
\hline Fund age in years at the start of the U.S. Treasury money fund guarantee & $0.083 * * *$ & $0.078 * * *$ & $0.072 * * *$ & $0.073 * * *$ & + \\
\hline Monthly return in September 2008 & 102.707 & -323.417 & -326.678 & -296.620 & - \\
\hline Share class expense ratio in September 2008 & 29.946 & -33.079 & 20.854 & 23.509 & + \\
\hline $\begin{array}{l}\text { Change in fund's assets under management (AUM) from September 12, } 2008 \text { to Sep- } \\
\text { tember 18, } 2008\end{array}$ & $8.446 * * *$ & $11.021 * * *$ & $9.770 * * *$ & $9.932 * * *$ & - \\
\hline Fund's yield in September 2008 & $55.003^{*}$ & 22.799 & $55.497 *$ & $54.452 *$ & + \\
\hline Constant & -1.430 & -1.611 & $-2.496^{*}$ & $-2.626^{* *}$ & None \\
\hline Number of observations where $Y=1$ & 1221 & 1221 & 1221 & 1221 & \\
\hline Number of observations where $Y=0$ & 111 & 111 & 111 & 111 & \\
\hline Pseudo $R$-squared & 0.192 & 0.220 & 0.216 & 0.214 & \\
\hline
\end{tabular}

AUM stands for assets under management. Statistical significances with 99, 95, and $90 \%$ confidence are denoted by coefficients with superscripts of $* * *, * *$, and $*$, respectively

\section{Conclusion}

The U.S. Treasury guaranteed $\$ 2.7$ trillion of money market mutual fund assets from September 19, 2008, to September 18,2009 . This paper uses a unique data set of the money funds participating in taxpayer and sponsor bailouts.

This paper finds that participation in taxpayer or sponsor bailouts was associated with participating the Fed's AssetBacked Commercial Paper Money Market Mutual Fund Liquidity Facility (AMLF) bailout for money funds. Thus, taxpayer and sponsor bailouts complemented the Fed bailouts of money market mutual funds.

In the most recent COVID-19 crisis, the Fed and U.S. Treasury have partnered to indirectly support money funds through the purchases of commercial paper issues by both corporations and municipalities in the restarted Commercial Paper Funding Facility (CPFF). In addition, the Fed has promised to support purchases of certificates of deposit and municipal variable rate demand notes though its new Money Market Mutual Fund Liquidity Facility (MMLF). See Federal Reserve (2020). To date, the money market mutual funds have not seen the distress experienced in 2008, and no guarantee of money funds similar to the one implemented in 2008 has been announced. CPFF, MMLF, and nine other Fed emergency lending programs have an up to $\$ 454$ billion U.S. Treasury backstop. Indeed, the markets have rallied since the eleven Fed emergency lending facilities were announced in March 2020, according to Smith and Fox (2020). We leave it for future work to look at the characteristics of beneficiaries of the latest round of U.S. government support for the financial sector.

In response to that bailout of money funds and the run triggered after the Reserve Primary Fund "broke the buck," reporting NAV losses of $\$ 0.03$ per share, the Securities and 
Table $6 t$-tests of means of money market mutual funds shares in which the fund's sponsors $\operatorname{did}(Y=1)$ and $\operatorname{did} \operatorname{not}(Y=0)$ obtain SEC approval to provide assistance to the fund in 2007 or 2008

$t$-tests of money market mutual funds shares in which the sponsors supported the fund according to the SEC

\begin{tabular}{|c|c|c|c|c|c|c|}
\hline Variable & Mean when $Y=1$ & Mean when $Y=0$ & Difference & $t$-stat. & $\begin{array}{l}\text { Number } \\
\text { of } Y=1 \\
\text { Obs. }\end{array}$ & $\begin{array}{l}\text { Number of } \\
Y=0 \text { Obs. }\end{array}$ \\
\hline $\begin{array}{l}\text { Adhered to } 2010 \text { SEC reforms' daily liquidity stand- } \\
\text { ard in September } 2008(Y=1, N=0)\end{array}$ & 0.785 & 0.647 & 0.137 & 0.697 & 316 & 1140 \\
\hline $\begin{array}{l}\text { Adhered to } 2010 \text { SEC reforms' weekly liquidity } \\
\text { standard in September } 2008(Y=1, N=0)\end{array}$ & 0.930 & 0.918 & 0.012 & $4.655^{* * *}$ & 316 & 1140 \\
\hline $\begin{array}{l}\text { Adhered to } 2010 \text { SEC reforms' WAM standard in } \\
\text { September } 2008(Y=1, \mathrm{~N}=0)\end{array}$ & 0.876 & 0.925 & -0.049 & $-2.744 * * *$ & 315 & 1084 \\
\hline $\begin{array}{l}\text { Adhered to } 2010 \text { SEC reforms' second-tier com- } \\
\text { mercial paper standard in September } 2008(Y=1 \text {, } \\
N=0)\end{array}$ & 1.000 & 0.998 & 0.002 & 0.745 & 316 & 1140 \\
\hline Second-tier commercial paper as \% of AUM & 0.000 & 0.017 & -0.017 & -1.142 & 316 & 1140 \\
\hline $\begin{array}{l}\text { Weighted average life (WAL) proxy, floating-rate } \\
\text { notes as \% of AUM }\end{array}$ & 12.813 & 9.994 & 2.819 & $3.038 * * *$ & 316 & 1140 \\
\hline $\begin{array}{l}\text { Participated in Federal Reserve's Asset-Backed Com- } \\
\text { mercial Paper Money Market Liquidity Facility } \\
\text { (AMLF) }(Y=1, N=0)\end{array}$ & 0.528 & 0.175 & 0.353 & $13.822 * * *$ & 320 & 1245 \\
\hline $\begin{array}{l}\text { Sponsor prevented fund from breaking the buck dur- } \\
\text { ing the financial crisis }(Y=1, N=0)\end{array}$ & 0.175 & 0.001 & 0.174 & $15.994 * *$ & 320 & 1245 \\
\hline $\begin{array}{l}\text { Sponsor injected money into the fund during the } \\
\text { financial crisis }(Y=1, N=0)\end{array}$ & 0.259 & 0.002 & 0.257 & $20.188 * * *$ & 320 & 1245 \\
\hline $\begin{array}{l}\text { Fund participated in U.S. Treasury's guarantee pro- } \\
\text { gram }(Y=1, N=0)\end{array}$ & 0.938 & 0.903 & 0.035 & $1.934^{*}$ & 320 & 1245 \\
\hline $\begin{array}{l}\text { Fund share identified as having NAV }<\$ 0.9975 \text { at } \\
\text { the start of U.S. Treasury guarantee program }(Y= \\
1, \mathrm{~N}=0)\end{array}$ & 0.206 & 0.078 & 0.128 & $6.507 * * *$ & 296 & 1119 \\
\hline Institutional fund $(Y=1, N=0)$ & 0.722 & 0.546 & 0.176 & $5.739 * *$ & 320 & 1245 \\
\hline Prime fund $(Y=1, N=0)$ & 0.703 & 0.406 & 0.297 & $9.767 * * *$ & 320 & 1245 \\
\hline Prime and institutional fund $(Y=1, N=0)$ & 0.453 & 0.198 & 0.256 & $9.690 * * *$ & 320 & 1245 \\
\hline Municipal or tax-free fund $(Y=1, N=0)$ & 0.097 & 0.190 & -0.094 & $-3.977 * * *$ & 320 & 1245 \\
\hline U.S. government fund $(Y=1, N=0)$ & 0.081 & 0.229 & -0.148 & $-5.967 * * *$ & 320 & 1245 \\
\hline U.S. Treasury fund $(Y=1, N=0)$ & 0.119 & 0.174 & -0.056 & $-2.403 * *$ & 320 & 1245 \\
\hline $\begin{array}{l}\text { Natural log of one plus assets under management in } \\
\text { USD billions }\end{array}$ & 0.651 & 0.569 & 0.082 & $1.658^{*}$ & 320 & 1245 \\
\hline $\begin{array}{l}\text { Fund age in years at the start of the U.S. Treasury } \\
\text { money fund guarantee }\end{array}$ & 9.976 & 11.475 & -1.498 & $-3.009 * * *$ & 320 & 1245 \\
\hline Monthly return in September 2008 & $0.166 \%$ & $0.140 \%$ & $0.026 \%$ & $9.609 * * *$ & 319 & 1242 \\
\hline Share class expense ratio in September 2008 & $0.514 \%$ & $0.604 \%$ & $-0.090 \%$ & $-3.712 * * *$ & 297 & 1206 \\
\hline $\begin{array}{l}\text { Change in fund's assets under management (AUM) } \\
\text { from September 12, } 2008 \text { to September 18, } 2008\end{array}$ & $-4.833 \%$ & $1.995 \%$ & $-6.827 \%$ & $-5.165 * * *$ & 314 & 1079 \\
\hline Fund's yield in September 2008 & $0.708 \%$ & $0.572 \%$ & $0.136 \%$ & $4.988 * * *$ & 320 & 1244 \\
\hline
\end{tabular}

AUM stands for assets under management. Statistical significances with 99, 95, and 90\% confidence are denoted by $t$-statistics with superscripts of ***,**, and *, respectively

Exchange Commission (SEC) tightened up the liquidity and maturity standards of money funds in 2010. It also introduced floating NAV regulations in 2014.

This paper tests looks at funds that adhered to the new 2010 requirements for money market funds in 2008 . Those tighter standards were generally not associated with any decreased propensity of funds to need taxpayer or sponsor bailouts. The exceptions were the reduction in the weighted average maturity WAM from 90 to 60 days and the penalty for holding auction rate securities in the new weighted average life (WAL) standard. Funds with WAM less than 60 days were significantly less likely to receive taxpayer guarantees or fund sponsor rescues during the financial crisis of 2007-to-2009. 
Table 7 Logistic regression of the propensity of money market mutual fund share classes to have their sponsors obtain SEC approval to bail out the fund between 2007 and 2008

\begin{tabular}{|c|c|c|c|c|c|}
\hline \multirow[b]{2}{*}{ Independent variable } & \multicolumn{4}{|l|}{ Coefficients } & \multirow{2}{*}{$\begin{array}{l}\text { Pred. } \\
\text { Sign }\end{array}$} \\
\hline & Model 1 & Model 2 & Model 3 & Model 4 & \\
\hline $\begin{array}{l}\text { Adhered to } 2010 \text { SEC reforms' daily liquidity standard in September } 2008(Y=1 \text {, } \\
\qquad N=0)\end{array}$ & 0.402 & $0.608 *$ & 0.496 & $0.600 *$ & - \\
\hline $\begin{array}{l}\text { Adhered to } 2010 \text { SEC reforms' weekly liquidity standard in September } 2008 \text { ( } Y= \\
1, N=0 \text { ) }\end{array}$ & -0.217 & -0.035 & 0.062 & -0.043 & - \\
\hline Adhered to 2010 SEC reforms' WAM standard in September $2008(Y=1, \mathrm{~N}=0)$ & -0.291 & $-0.609 * *$ & $-0.605 * *$ & $-0.589 * *$ & - \\
\hline Weighted average life (WAL) proxy, floating-rate notes as \% of AUM & $-0.012 *$ & $-0.013 * *$ & $-0.015^{* *}$ & $-0.014 *$ & + \\
\hline $\begin{array}{l}\text { Participated in Federal Reserve's Asset-Backed Commercial Paper Money Market } \\
\text { Liquidity Facility (AMLF) }(Y=1, N=0)\end{array}$ & $0.955^{* * *}$ & $0.858 * * *$ & $0.974 * * *$ & $0.832 * * *$ & + \\
\hline Fund participated in U.S. Treasury's guarantee program $(Y=1, N=0)$ & 0.273 & & & & + \\
\hline $\begin{array}{l}\text { Fund share identified as having NAV }<\$ 0.9975 \text { at the start of U.S. Treasury } \\
\text { guarantee program }(Y=1, N=0)\end{array}$ & & $1.199 * * *$ & $1.166 * * *$ & $1.198 * * *$ & + \\
\hline Institutional fund $(Y=1, N=0)$ & $0.609 * * *$ & $0.541 * * *$ & & $0.556^{* * * *}$ & + \\
\hline Prime fund $(Y=1, N=0)$ & 0.348 & $0.571 *$ & & $0.576 *$ & + \\
\hline Prime and institutional fund $(Y=1, N=0)$ & & & 0.106 & & + \\
\hline Municipal or tax-free fund $(Y=1, N=0)$ & -0.232 & -0.008 & -0.240 & & - \\
\hline U.S. government fund $(Y=1, N=0)$ & $-0.015 * * *$ & $-0.010 *$ & $-0.012 * *$ & $-0.010^{*}$ & - \\
\hline Natural log of one plus assets under management in USD billions & -0.038 & -0.078 & -0.107 & & + \\
\hline Fund age in years at the start of the U.S. Treasury money fund guarantee & -0.010 & -0.013 & $-0.019 *$ & -0.015 & + \\
\hline Monthly return in September 2008 & $1063.529 * *$ & $924.203^{* *}$ & $1230.046 * * *$ & $932.848 * *$ & - \\
\hline Share class expense ratio in September 2008 & $73.147 *$ & 38.690 & 32.642 & 47.140 & + \\
\hline $\begin{array}{l}\text { Change in fund's assets under management (AUM) from September 12, } 2008 \text { to } \\
\text { September 18, } 2008\end{array}$ & $0.035 * * *$ & -0.481 & -0.788 & -0.504 & - \\
\hline Fund's yield in September 2008 & $33.018^{*}$ & 19.309 & 16.289 & 21.040 & + \\
\hline Constant & $-4.134 * *$ & $-3.653 * * *$ & $-3.314 * * *$ & $-3.758 * * *$ & None \\
\hline Number of observations where $Y=1$ & 1040 & 946 & 946 & 946 & \\
\hline Number of observations where $Y=0$ & 292 & 269 & 269 & 269 & \\
\hline Pseudo $R$-squared & 0.155 & 0.183 & 0.177 & 0.183 & \\
\hline
\end{tabular}

AUM stands for assets under management. Statistical significances with 99,95 , and $90 \%$ confidence are denoted by coefficients with superscripts of $* * *, * *$, and $*$, respectively

The SEC's 2014 floating NAV regulations were applied to institutional prime and municipal funds. The paper finds that prime and municipal funds were significantly more likely to take taxpayer bailouts, but institutional funds were not. In contrast, sponsor bailouts were significantly more likely with institutional funds, but were not significantly more likely with prime or municipal MMMFs. Thus, the paper gives some limited support for the floating NAV requirements as preventing future bailouts of money market mutual funds (MMMFs).

\section{Appendix: A back of the envelope calculation of the cost of insuring money funds}

If federal insurance is offered for money funds, it seems likely that fund sponsors will no longer feel compelled to rescue federally insured funds. If that happens, the cost of insuring money funds is greater than the $\$ 1.2$ billion in premiums collected for insuring $\$ 2.7$ trillion in money fund assets for a year. Below, it is estimated that the insurance for money market mutual funds represented a $\$ 2.3$ billion to- $\$ 7.8$ billion subsidy to the recipient mutual funds.

\section{Lower estimate}

Based on the Moody's (2010) data over 30 years from 1980 to 2009 , there were 208 instances of sponsor bailouts for money funds. Three funds broke the buck. (Two funds 
breaking the buck were U.S. based.) By the end of 2009, $85 \%$ of the money market funds were based in the U.S. The TTGMMMF guaranteed $97 \%$ of U.S. fund assets, according to my estimates. The average private bailout of money funds, according to Moody's between 2007 and 2010, was $\$ 0.607$ billion. The TTGMMMF collected $\$ 1.2$ billion in premiums.

Minimum premium (low estimate)

$$
\begin{aligned}
& =(211) /(30) *(0.97) *(0.85) *(\$ 0.607 \text { billion }) \\
& =\$ 3.5 \text { billionFederal subsidy (low })=\$ 3.5 \text { billion } \\
& -\$ 1.2 \text { billion }=\$ 2.3 \text { billion }
\end{aligned}
$$

\section{Higher estimate}

The financial crisis had many more sponsor bailouts of money market mutual funds than a typical year between 1980 and 2009. In the U.S., between August 2007 and December 2009, there were 36 sponsor bailouts and one fund breaking the buck. That is a 2.42 -year period. The federal guarantee lasted one year from September 19, 2008, to September 18, 2009.

Minimum premium (high estimate)

$$
\begin{aligned}
& =(37 / 2.42) *(0.97) *(\$ 0.607 \text { billion })=\$ 9.0 \text { billion } \\
& \text { Federal subsidy }(\text { high })=\$ 9.0 \text { billion }-\$ 1.2 \text { billion }=\$ 7.8 \text { billion }
\end{aligned}
$$

It appears that the insurance that taxpayers provided was greatly underpriced. Taxpayers are fortunate to have turned a profit. There is no evidence that the U.S. Treasury did any analysis to ensure that the premiums were fairly priced. It was a program rolled out almost overnight.

I have not built in any compensation for risk in these estimates. Thus, I believe investors providing such insurance would demand premiums higher than I have indicated in this range. Yet, the stigma of tapping federal guarantees may have prompted some sponsors to bail out the funds with federal insurance. Thus, in that case, these estimates may be too high.

$\$ 2.716$ trillion in assets were insured by the U.S. Treasury's guarantee. In basis points, the zero subsidy cost of the insurance should have been $10,000 *(\$ 3.5$ billion $) /(\$ 2716$ billion $)=13$ basis points to $10,000 *(\$ 9.0$ billion $) /(\$ 2716$ billion $)=33$ basis points. Taxpayers charged on average $10,000 *(\$ 1.2 / \$ 2716)=4.4$ basis points. Thus, the fair price of insurance was closer to 13-to-33 basis points, but taxpayers charged 4.4 basis points during the crisis period. Today, the money fund industry pays no insurance premiums to taxpayers or an industry fund similar to the deposit insurance fund, but there is likely some market expectation that it will benefit from underpriced insurance during the next crisis.

\section{References}

Agapova, Anna. 2011. The Role of Money Market Mutual Funds in Mutual Fund Families. Journal of Applied Finance 21 (1): $87-102$.

Baily, Martin N., John Y. Campbell, John H. Cochrane, Douglas W. Diamond, James Darrell Duffie, Kenneth R. French, Anil K. Kashyap, Frederic S. Mishkin, David S. Scharfstein, Robert J. Shiller, Matthew J. Slaughter, Hyun Song Shin, Jeremy C. Stein, Rene M. Stulz. 2011. Reforming Money Market Funds. SSRN Working Paper, accessed online on March 22, 2019, at https:// ssrn.com/abstract $=1740663$.

Birdthistle, William A. 2010. Breaking Bucks in Money Market Funds. Wisconsin Law Review 5: 1155-1201.

Brady, Steffanie A., Ken E. Anadu, and Nathaniel Cooper. 2012. The Stability of Prime Money Market Mutual Funds: Sponsor Support from 2007 to 2011. Federal Reserver Bank of Boston, Risk and Policy Analysis Unit, Working Paper RPA 12-3, August 13, 2012.

Duygan-Bump, Burcu, Patrick M. Parkinson, Eric S. Rosengren, Gustavo A. Suarez, and Paul S. Willen. 2013. How Effective Were the Federal Reserve Emergency Liquidity Facilities? Evidence from the Asset-Backed Commercial Paper Money Market Mutual Fund Liquidity Facility. Journal of Finance 68 (2): 715-737.

Federal Reserve. 2020. Press Release: Federal Reserve announces extensive new measures to support the economy. Board of Governors of the Federal Reserve, March 23, 2020, accessed online on June 4, 2020, at https://www.federalreserve.gov/newsevents/ pressreleases/monetary20200323b.htm.

Register, Federal. 2010. Money Market Fund Reform; Final Rule: Part III Securities and Exchange Commission 17 CFR Parts 270 and 274. Federal Register 75 (42): 10060-10120.

Fisch, Jill E., and Eric Roiter. 2012. A Floating NAV for Money Market Funds: Fix or Fantasy? University of Illinois Law Review 4: 1003-1050.

Fisch, Jill E. 2015. The Broken Buck Stops Here: Embracing Sponsor Support in Money Market Fund Reform. North Carolina Law Review 93 (4): 935-993.

Gandia, Christopher M., and Jeffrey Gordon. 2014. Money Market Funds Run Risk: Will Floating Net Asset Value Fix the Problem? Columbia Business Law Review 2: 314-332.

Han, Song, and Dan Li. 2010. The Fragility of Discretionary Liquidity Provision: Lessons from the Collapse of the Auction Rate Securities Market. Finance and Economics Discussion Series 2010-50. Board of Governors of the Federal Reserve System (U.S.).

Hensler, Timothy B. 2012. Letter to The Honorable Richard Shelby, Ranking Member, Committee on Banking, Housing, and Urban Affairs, U.S. Senate, Re: List of Money Market Mutual Funds Receiving Sponsor Support, July 31, 2012. U.S. Securities and Exchange Commission, Office of Legislative Affairs.

Kacperczyk, Marcin, and Phillipp Schnabl. 2013. How Safe are Money Market Funds? Quarterly Journal of Economics 128 (3): 1073-1122.

Gabriele, La Spada. 2018. Competition, Reach for Yield, and Money Market Funds. Journal of Financial Economics 129: 87-110.

Liu, Baixiao, John McConnell, and Alessio Saretto. 2010. Why Did Auction Rate Bond Auctions Fail During 2007-2008? Journal of Fixed Income 20: 5-18.

Kim, Hugh H. 2019. Information Spillover of Bailouts. Journal of Financial Intermediation. https://doi.org/10.1016/j. jfi.2018.12.001. 
McCabe, Patrick E. 2010. The Cross Section of Money Market Fund Risks and Financial Crises. Finance and Economics Discussion Series Divisions of Research \& Statistics and Monetary Affairs, Federal Reserve Board, Washington, D.C. 2010-51.

McConnell, John, and Alessio Saretto. 2010. Auction Failures and the Market for Auction Rate Securities. Journal of Financial Economics 97: 451-469.

Moody's. 2010. Sponsor Support Key to Money Market Funds, Special Comment, 9 August 2010. Moody's Investors Service.

Morgenson, Gretchen. 2012. August 11, 2012, Breaking the Buck, Maybe, But Not Taxpayers' Backs. New York Times, B1, B6.

Parlatore, Cecilia. 2016. Fragility in Money Market Funds: Sponsor Support and Regulation. Journal of Financial Economics 121: 595-623.

Pavlov, Andrei D., and Susan M. Wachter. 2002. Robbing the Bank: Non-recourse Lending and Asset Prices. Journal of Real Estate Finance and Economics 28: 147-160.

Pavlov, Andrei D., and Susan M. Wachter. 2009a. Mortgage Put Options and Real Estate Markets. Journal of Real Estate Finance and Economics 38: 89-103.

Pavlov, Andrei D., and Susan M. Wachter. 2009b. Systemic Risk and Market Institutions. Yale Journal on Regulation 26: 445-455.

Schmidt, Lawrence, Allan Timmermann, and Russ Wermers. 2016. Runs on Money Market Mutual Funds. American Economic Review 106 (9): 2625-2657.

SEC. 2012. Response to Questions Posed by Commissioners Aguilar, Paredes, and Gallagher. Division of Risk, Strategy, and Financial Innovation U.S. Securities and Exchange Commission, accessed online on December 30, 2012, at http://www.sec.gov/news/studi es/2012/money-market-funds-memo-2012.pdf.

SEC. 2014. Press Release: SEC Adopts Money Market Fund Reform Rules.

Smith, Colby, and Brooke Fox. 2020. Fraction of Fed Lending Facilities Have Been Tapped So Far. Financial Times, May 27, 2020, accessed online on June 4, 2020, at https://www.ft.com/content/ a1fba7cd-5329-46e6-82a8-57149e409f6c.

Witmer, Jonathan. 2016. Does the Buck Stop Here? A Comparison of Withdrawals from Money Market Mutual Funds with Floating and Constant Share Prices. Journal of Banking \& Finance 66 (5): 126-142.

Wilson, Linus. 2011. A Binomial Model of Geithner's Toxic Asset Plan. Journal of Economics and Business 63 (5): 349-371.

Wilson, Linus. 2012. Toxic Asset Subsidies and the Early Redemption of TALF Loans. SSRN Working Paper, accessed online on March 22, 2019, at http://ssrn.com/abstract $=1742640$.

Wilson, Linus and Wendy Yan Wu. 2017. Characteristics of Participants in the Commercial Paper Funding Facility. SSRN Working Paper, accessed online on March 22, 2019, at http://ssrn.com/ abstract $=1911454$.

Wilson, Linus, and Wendy Yan Wu. 2018. Overpaid CEOs Got FDIC Debt Guarantees. North American Journal of Economics and Finance 45: 101-115.

Wilson, Linus, Wu Wendy Yan, and Stephanie Prejean. 2014. Are the Bailouts of Wall Street Complements or Substitutes? Atlantic Economic Journal 42 (1): 21-38.

Publisher's Note Springer Nature remains neutral with regard to jurisdictional claims in published maps and institutional affiliations.

Linus Wilson is the author of over forty peer-reviewed journal articles. He earned his doctorate in financial economics from University of Oxford in 2007. His work on the bailouts during the financial crisis of 2008 and 2009 has been sourced in over two hundred national or international news articles including the New York Times, Financial Times, and Wall Street Journal. He serves as an Associate Professor of Finance at the University of Louisiana at Lafayette. 